ORIGINAL ARTICLE

\title{
Impact of soil properties, tree layer and grass cover on forest regeneration in a mixed native species reforestation
}

\author{
Impacto de propriedades do solo, do estrato arbóreo e da cobertura por \\ gramíneas em um reflorestamento heterogêneo com espécies arbóreas nativas
}

Michel Anderson Almeida Colmanetti ${ }^{1}$ (D), Luiz Mauro Barbosa ${ }^{2}$ (D), Hilton Thadeu Zarate do Couto ${ }^{3}$ (D), José Carlos Casagrande ${ }^{4}$ (D), Regina Tomoko Shirasuna ${ }^{2}$ (D), Paulo Roberto Torres Ortiz ${ }^{2}$ (D), Renato Paiva de Lima $^{5}$ (D), Miguel Magela Diniz ${ }^{6}$ (1)

\author{
${ }^{1}$ Empresa Brasileira de Pesquisa Agropecuária - EMBRAPA, Campinas, SP, Brasil \\ ${ }^{2}$ Instituto de Botânica de São Paulo - IBT, São Paulo, SP, Brasil \\ ${ }^{3}$ Universidade de São Paulo - USP, Piracicaba, SP. Brasil \\ ${ }^{4}$ Universidade Federal de São Carlos - UFSCar, Araras, SP, Brasil \\ ${ }^{5}$ Universidade Federal Rural de Pernambuco - UFRP, Recife, PE, Brasil \\ ${ }^{6}$ International Paper - International Paper Brasil, Mogi-Guaçú, SP, Brasil
}

How to cite: Colmanetti, M. A. A., Barbosa, L. M., Couto, H. T. Z., Casagrande, J. C., Shirasuna, R. T., Ortiz, P. R. T., Lima, R. P., Diniz, M. M. (2021). Impact of soil properties, tree layer and grass cover on forest regeneration in a mixed native species reforestation. Scientia Forestalis, 49(130), e3312. https://doi.org/10.18671/scifor.v49n130.23

\begin{abstract}
Natural forest recruitment is important for maintaining reforestation over time. Different variables simultaneously influence the development of the regenerating layer and are fundamental to the success of reforestation. The main objective of this study was to assess the interference and facilitation imposed by soil, canopy and invasive African grasses on species richness, species diversity, numbers of individuals, and the average height of the natural forest recruitment at Mogi-Guaçú, Brazil. The covariates assessed were: soil chemical and physical properties, tree layer, and invasive African grasses. The most significant covariates for tree regeneration indicators were the cation exchange capacity, water availability in soil, clay content, canopy openness, aboveground biomass of the tree layer, and grass cover. We conclude that soil properties did not impose a limitation to natural forest recruitment. In contrast, invasive grass cover interfered negatively on the diversity and structure of the tree regeneration.
\end{abstract}

Keywords: Revegetation; Soil; Invasive African grasses.

\section{Resumo}

O recrutamento de indivíduos regenerantes em florestas naturais é fundamental para manter o reflorestamento ao longo do tempo. Diferentes variáveis exercem influência, simultaneamente, no desenvolvimento da estrato regenerante e são fundamentais para o sucesso do reflorestamento. O principal objetivo deste estudo foi avaliar a interferência e facilitação impostas pelo solo, dossel e gramíneas exóticas invasoras ao número de indivíduos, riqueza de espécies, diversidade de espécies e altura média do estrato regenerante, em um reflorestamento em Mogi-Guaçú, Brasil. As covariávies

Financial support: None.

Conflict of interest: None.

Correspondig author: michelcolmanetti@gmail.com

Received: 14 March 2019.

Accepted: 15 June 2020.

Editor: Paulo Henrique Müller Silva.

(c) (i) This is an Open Access article distributed under the terms of the Creative Commons Attribution License, which permits unrestricted use, distribution, and reproduction in any medium, provided the original work is properly cited. 
analisadas foram: propriedades químicas e físicas do solo, estrutura do estrato arbóreo e gramíneas invasoras africanas. As covariáveis que apresentaram significância estatística foram: capacidade de troca catiônica, água disponível no solo, argila, abertura do dossel, biomassa do estrato arbóreo e cobertura de gramíneas. Conclui-se que as propriedades do solo não foram limitantes ao desenvolvimento do estrato regenerante. Porém, a cobertura de gramíneas invasoras interferiu negativamente na estrutura e diversidade do estrato regenerante.

Palavras-chave: Revegetação; Solo; Gramíneas africanas invasoras.

\section{INTRODUCTION}

Reforestation with a high number of native species has been used as a restoration technique to restore the deforested areas in Brazil (Rodrigues et al., 2009, 2011). Based on the assumptions of the secondary succession in spatial and temporal scales (Denslow, 1987; Denslow \& Guzman, 2000; Guariguata \& Ostertag, 2001; Sapkota \& Odén, 2009; Chazdon et al., 2010), species from different functional groups have been used in those plantations.

While it is reasonable to accept that secondary succession may elucidate current problems in restoration, application requires constant improvement of existing techniques. For ecological restoration in reforestation, it was expected that the recovery of natural regeneration under the canopy would promote forest maintenance. Natural regeneration is an important key to maintaining the forests over time, as the natural forest recruitments must guarantee the species richness and diversity (Shono et al., 2006; Pereira et al., 2013). To investigate the potential limitations imposed on the lower canopy (regeneration layer) is important to verify the effectiveness of the silvicultural techniques used in reforestation with native species.

Many studies have evaluated the performance of the reforestation plantations (Leitão et al., 2010; van Breugel et al., 2011; Meli \& Dirzo, 2013; Sobanski \& Marques, 2014) and natural forest regeneration (Holl, 1998; Holl, 1999; Leitão et al., 2010). The negative interference of the invasive plants on the natural regenerates are well known in the literature (Sharma \& Raghubanshi, 2010; Damasceno et al., 2018). Invasive plants, especially grasses, interfere with seed germination and seedling establishment, reducing the growth of seedlings in natural regeneration, and altering the structure and composition of the natural regeneration, as is the fire regime for some forest types (D'Antonio \& Vitousek, 1992; D'Antonio et al., 1998; Damasceno et al., 2018).

Canopy openness in forest regeneration regulates the light input affecting natural forest recruitment (Guariguata \& Ostertag, 2001). This is particularly important for seasonal forests where the light regime varies throughout the year (Gandolfi et al., 2007), but better understanding of this phenomenon in tropical reforestation with native species is needed.

Site-scale soil conditions also play an important role in the natural forest regeneration. The physical and chemical qualities of the soil affect the growth and development of above- and belowground parts of plants. Water availability, aeration, mechanical impediment, and nutrient load are the dominant soil conditions that affect plant growth, but indicators of soil quality such as bulk density, porosity, clay content, and cation exchangeability are also important variables within the soil-plant system 
(Filho et al., 2013; da Silva et al., 2014). It is challenging to establish a generalist relationship between soil properties and reforestation success due to the variability of soil conditions prior to land-use change, such as conversion of arable land to forest. However, it is reasonable to assume that improvements in physical and chemical qualities of the soil are associated with improved forest regeneration.

Since invasive species (Damasceno et al., 2018), soil conditions (van Breugel et al., 2011), and canopy openness (Sharma \& Raghubanshi, 2010) impose limitations to natural forest recruitment at different levels, we propose the integration of these multiple levels of information to provide a more parsimonious framework for the potential effect of the different covariates on the natural forest recruitment. It is expected that the combination of several variables in a single model may provide a more realistic scenario than analyzing them separately. This study investigates the explanatory covariates of soil condition, invasive grass cover (by African grasses), and tree layer that affect natural forest regeneration during reforestation with native species. These explanatory covariates were integrated with previous models to explain the height, population size, species richness, and diversity for natural forest recruitment.

\section{MATERIALS AND METHODS}

\subsection{Study site}

The study was conducted from 2011 to 2012 at São Marcelo Forest Park (SMFP; $22^{\circ}$ $22^{\prime}$ S, 46 58' W) in Mogi-Guaçu city, São Paulo State, Brazil; a private natural heritage reserve belonging to International Paper of Brazil, Ltd. SMFP is a 240 ha reforestation project created and planted in 2002 using 100 Brazilian native species of seedlings (see list of species in Colmanetti, 2013). Each species did not exceed the limit of $20 \%$ of the total number of seedlings planted. At planting, species were classified into early and late successional groups, and the seedlings were distributed as a framework in the field, alternating between groups at a spacing of $3.0 \times 2.5 \mathrm{~m}$. The Köppen climate of the region is Cwa, characterized by dry winters and hot summers (Alvares et al., 2013). Two soil types were present at SMFP: Oxisol and Ultisol (Soil Survey Staff 2014). Before conversion to a reserve, the soil in the park was used for annual cultures such as sugarcane, perennials such as coffee or citrus, and pasture. From 1995 to 2002, it was used as a Eucalyptus sp. plantation. In 2002, the soil was mechanically tilled using a three stem subsoiler at a depth of 40 to $60 \mathrm{~cm}$. Fertilization of all seedlings was performed by using NPK 10:30:10 (1\% B, 0.5\% Zn). A supplementary planting to replace the seedlings that had died was performed over the total area (240 ha), about 60 days after planting, using the same technique and species used in the first plating. Five post-emergent herbicide treatments (glyphosate) were also performed in and between rows to control invasive species. Ant control was performed once pre-planting and three times postplanting with the ant poison sulfluramide, at a dose of $10 \mathrm{~g} \mathrm{~m}^{-2}$.

The original local native vegetation at SMFP was mostly represented by tropical semi-deciduous forest and broad sense Cerrado (Neotropical Savannah), but most forests had been converted into farms and Eucalyptus sp. plantations. The most significant surrounding native vegetation is a 
fragment located in a private farm at a distance of approximately $10 \mathrm{~km}$. The largest forest remnant is the Mogi-Guaçu Biological Reserve, at a distance of approximately $30 \mathrm{~km}$.

\subsection{Vegetation sampling of natural forest recruitment}

The individuals and species originated by the natural regeneration were defined as natural forest recruitment. The study was conducted in 20 plots with $12.5 \times 18 \mathrm{~m}$ $\left(225 \mathrm{~m}^{2}\right)$, and natural forest recruitments, (height $\geq 30 \mathrm{~cm}$ and diameter at breast height $(d b h)<4.8 \mathrm{~cm}$ ) were measured to determine the regeneration layer. All individuals were identified to species, genus, or family according to Brazilian Species Flora List and Missouri Botanical Garden Families were organized using the system APG IV (Stevens, 2001). More details regarding the floristic composition and the successional groups are available at Colmanetti et al. (2016) and Colmanetti (2013). For natural forest recruitments, the number of individuals by plot was obtained by summing all individuals from the regeneration layer in each plot. The richness of species was the number of species (or genera, when species level identification was not available) by plot. The average height for all recruitment individuals in the plots was obtained. The species diversity (Equation 1) was calculated for each plot according to Simpson (1949)

$\mathrm{D}=1-\sum\left(\mathrm{n}_{\mathrm{i}}\left[\mathrm{n}_{\mathrm{i}}-1\right] / \mathrm{N}[\mathrm{N}-1]\right)$

where $n_{i}=$ individuals of $i$ species and $N=$ total number of individuals.

\subsection{Grass cover by African grasses}

A single percentage value of openness was obtained using an observation on 50 symmetrically distributed points within each plot. The grass cover by African grasses was predominantly represented by two invasive species, (Megathyrsus maximus (Jacq.) B.K. Simon and Urochloa brizantha (Hochst. ex A. Rich.) R.D. Webster. We recorded the presence or absence of invasive African grasses at each point and a single percentage value of openness was obtained for each plot.

\subsection{Canopy openness and aboveground biomass of the tree layer}

All individuals from the tree layer (trees with $d b h \geq 4.8 \mathrm{~cm}$ ) were identified at specie-, genus-, and family-level, and the $d b h$ were measured. The details regarding the floristic composition are available at Colmanetti \& Barbosa (2013) and Colmanetti (2013). An additional information of canopy openness was taken and aboveground biomass (AGB) was calculated. Canopy openness estimates were obtained by using a Densitometer and estimates of canopy openness (\%) were calculated by an average of the absence in relation to the total of measurements from 100 points symmetrically distributed within each plot. Additional measurements of canopy openness and grass cover variation were taken during the rainy season to account for forest seasonality; however, no improvement in explanatory ability was observed when this information was added to the model.

Estimates for AGB $\left(\mathrm{Mg} \mathrm{ha}^{-1}\right)$ for the tree layer (diameter $\geq 4.8 \mathrm{~cm}$ ) were obtained by summing the predicted individual tree biomass by plots. The individual tree biomass ( $a g b$; 
Equation 2) was predicted using the model proposed by Sotomayor (2013) fitted for a similar forest type also located in southern Brazil.

$\mathrm{agb}=0.0714474 \mathrm{dbh}^{(2.5501742)}$

where $d b h$ is diameter at breast height.

\subsection{Soil sampling and analysis}

All soil samples were collected at three depths: 0-10, 0-20, and 20-40 cm. For the chemical analysis, samples were taken using a Dutch Auger and were composed by collecting ten subsamples systematically distributed within the plots $(12.5 \times 18 \mathrm{~m})$. The samples were analyzed according to Camargo et al. (1986) for organic matter (OM), potassium dichromate, $\mathrm{P}$ (resin), $\mathrm{H}+$ $\mathrm{Al}$ (Solution SMP), K, Ca, and Mg (resin). We calculated sum of bases (SB) using the sum of K, Ca, and $\mathrm{Mg}$, cation exchange capacity (CEC) from the sum of $\mathrm{H}+\mathrm{Al}$ and $\mathrm{SB}$, and saturation by bases (V\%) as the percent of SB in CEC.

For physical analysis, samples were taken by using a steel cylinder $\left(100 \mathrm{~cm}^{3}\right)$. Soil cores were analyzed following Teixeira et al. (2017), for granule measures (sand, silt, and clay, determined by the pipette method), soil bulk density (BD; determined by the steel cylinder method); field capacity ( $F C$; pressure plate apparatus, $330 \mathrm{hPa}$ ), and permanent wilting point (PWP; pressure plate apparatus, $15,000 \mathrm{hPa}$ ). Water availability (WA, $\mathrm{g} \mathrm{g}^{-1} \%$ ) was calculated as the difference between FC and PWP.

\subsection{Data analysis}

We performed mixed-effect linear models for the number of individuals, average height, species diversity, and richness of species from the tree regenerating layer. We used potential covariates from soil ( $\mathrm{P}, \mathrm{OM}, \mathrm{V} \%, \mathrm{CEC}, \mathrm{BD}$; WA, and clay content), the grass cover by invasive African grasses, canopy openness (CO), and AGB. Sample depth was tested as a potential factor, but there was no improvement in explanatory ability when it was added to the model. To select potential covariates, we performed a Pearson correlation for tree regenerating variables and all independent covariates (Appendix 1). The additional information of the grass cover by African species and canopy cover from the rainy season did not improve model explanatory; therefore, only information from the dry season was used. The best models were chosen by Akaike Information Criteria (AIC) and graphical analysis of residuals. Model fitting was confirmed by $\mathrm{R}^{2}$-marginal (fixed effects) and $R^{2}$-conditional (fixed effects plus the random) using the package MuMIn in R (R Core Team, 2018).

A multilevel random effect nesting the plot groups within soil type (Oxisol and Ultisol) was used as a potential multilevel group, but no improvement was observed. Correlograms of the residuals were used to check autocorrelation between the plots. All analyses were performed in R (R Core Team, 2018). 


\section{RESULTS AND DISCUSSION}

\subsection{Summary of the tree regenerating vegetation and covariates}

A high variation for average height, number of individuals, species richness, and species diversity of the regenerating tree layer was observed (Table 1). For covariates, a high variation was also observed for the AGB, canopy openness, and grass cover by invasive African species. Some large individuals $(d b h>25 \mathrm{~cm})$ from fast-growing species such as Schizolobium parahyba (Vell.) Blake, Cedrela odorata L., Guazuma ulmifolia Lam., Cytharexyllum myrianthum Cham played an important role on tree AGB at tree layer (Appendix 2). Overall, 62 tree species were identified in the natural forest recruitments, and an average of 13 species per plot was observed (Appendix 3). Grass cover was predominated by two exotic and invasive African species, Megathyrsus maximus and Urochloa brizantha (Table 1).

Table 1. Summary of the tree regeneration layer, grass cover, and tree layer of reforestation at the Private Natural Heritage Reserve São Marcelo Forest Park, Mogi-Guaçu, São Paulo State, Brazil.

\begin{tabular}{ccc}
\hline Variable & Mean (sd) & Range \\
\hline Average height $(\mathrm{m})$ & $0.74 \pm 0.28$ & $0.11-1.34$ \\
Number of individuals & $179.6 \pm 155.8$ & $23-584$ \\
Richness of species & $12.7 \pm 4.47$ & $6-18$ \\
Species diversity & $0.32 \pm 0.14$ & $0.16-0.63$ \\
Canopy openness (\%) & $30.8 \pm 7.6$ & $15-45$ \\
Aboveground biomass (Mg ha-1) & $38.9(18.5)$ & $18.1-91.9$ \\
Grass cover (\%) & $44.7 \pm 31.1$ & $0-94$
\end{tabular}

A high variation was observed for soil variables (Table 2). Phosphorus resin (P), organic matter (OM), and base saturation ( $\mathrm{V} \%$ ) increased according to the depth (Figure 1). We observed a difference in OM, CEC, BD, and WA between Oxisol and Ultisol.

Table 2. Summary of soil covariates at the Private Natural Heritage Reserve São Marcelo Forest Park, Mogi-Guaçu, São Paulo State, Brazil.

\begin{tabular}{ccc}
\hline Soil Covariates & Mean (sd) & Range \\
\hline Phosphorus resin $\left(\mathrm{mg} \mathrm{dm}^{-3}\right)$ & $4.2 \pm 3.2$ & $1-18$ \\
Organic matter $\left(\mathrm{g} \mathrm{dm}^{-3}\right)$ & $26.7 \pm 6.4$ & $14-41$ \\
Cation exchange capacity $\left(\mathrm{mmol} \mathrm{dm}^{-3}\right)$ & $70.8 \pm 14.6$ & $39.4-126.8$ \\
Base saturation (\%) & $47.4 \pm 24.5$ & $7.3-87.7$ \\
Bulk density $\left(\mathrm{Mg} \mathrm{m}^{-3}\right)$ & $1.4 \pm 0.1$ & $1.0-1.7$ \\
Water availability $\left(\mathrm{g} \mathrm{g}^{-1}, \%\right)$ & $6.5 \pm 2.4$ & $0.6-12.94$ \\
Clay content $(\%)$ & $44.5 \pm 10.3$ & $18-74$
\end{tabular}




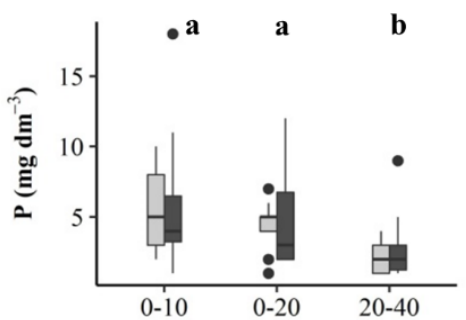

(A)

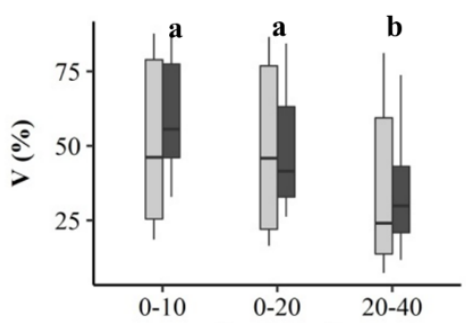

(C)

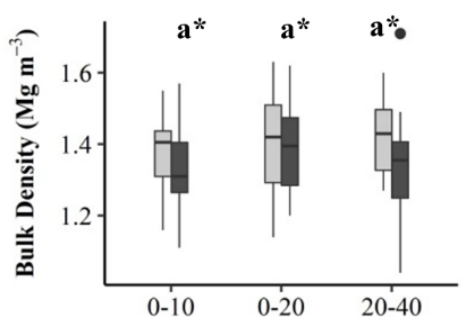

(E)

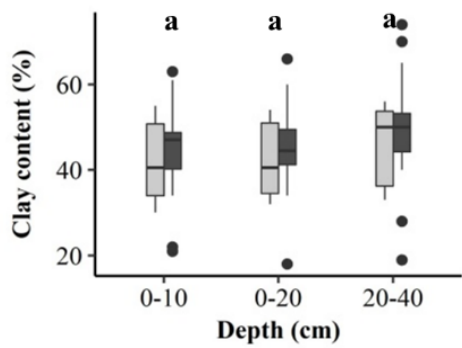

(G)

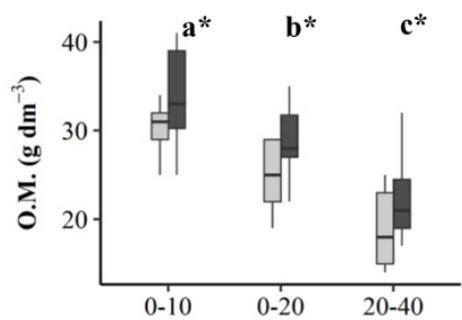

(B)

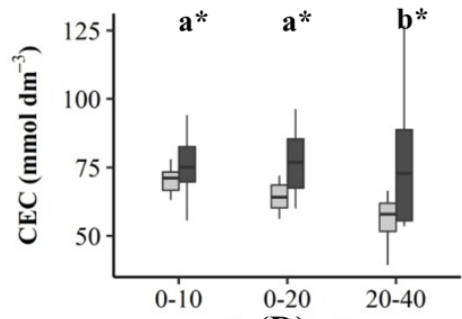

(D)

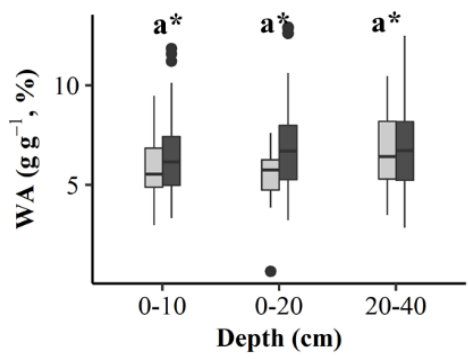

(F)

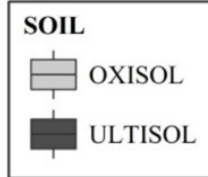

Figure 1. Chemical and physical soil variables for three depths (0-10, 0-20 and 20-40 cm) and two soil types (Oxisol and Ultisol) in the Private Natural Heritage Reserve São Marcelo Forest Park, Mogi-Guaçu, São Paulo State, Brazil. Different letters indicate statistical differences at 95\% level of confidence varying the depth. * Statistical differences at 95\% level of confidence varying the soil type. (A) P at three depths in two soil types; (B) Organic Matter at three depths in two soil types; (C) V\% at three depths in two soil types; (D) Cation Exchange Capacity at three depths in two soil types; (E) Bulk Density at three depths in two soil types; (F) Water availability $\left(\mathrm{g} \mathrm{g}^{-1}, \%\right)$ at three depths in two soil types; (G) Clay content (\%) at three depths in two soil types.

\subsection{The impact of chemical and physical soil properties on the tree regeneration layer}

The models for the number of individuals, species richness, and regenerates height had higher R-squared than species diversity (Table 3). In general, soil covariates (CEC and WA) had a positive correlation to tree regenerating vegetation except clay content for average height, 
showing that soil did not impose any restriction to natural forest recruitment. We did not observe any explanatory improvement on model performance by adding soil type and depth.

Table 3. Models for average height, number of individuals, species richness, and species diversity of the tree regeneration in the Private Natural Heritage Reserve São Marcelo Forest Park, Mogi-Guaçu, São Paulo State, Brazil. ** Statistical significance at 95\% level of confidence.

\begin{tabular}{ccccc}
\hline & \multicolumn{4}{c}{ Average Height $(\mathbf{m})$} \\
\hline & Estimates & $\operatorname{Pr}(>|\mathbf{t}|)$ & R-marginal & R-conditional \\
\hline Intercept & 2.023 & $<0.001 * *$ & \\
Clay content (\%) & -0.016 & $<0.001 * *$ & & 0.93 \\
Canopy Openness (\%) & -0.025 & $<0.001 * *$ & 0.74 & \\
Aboveground biomass (Mg ha $\left.{ }^{-1}\right)$ & 0.004 & $<0.001 * *$ & &
\end{tabular}

\begin{tabular}{|c|c|c|c|c|}
\hline \multicolumn{5}{|c|}{ Numbers of Individuals } \\
\hline & Estimates & $\operatorname{Pr}(>|t|)$ & R-marginal & R-conditional \\
\hline Intercept & 158.1 & $<0.05^{*}$ & \multirow{4}{*}{0.08} & \multirow{3}{*}{0.99} \\
\hline CEC & 0.53 & 0.059 & & \\
\hline WA & 4.88 & $<0.05^{\star}$ & & \\
\hline Grasses Cover (\%) & -0.90 & $<0.001 * \star$ & & \\
\hline
\end{tabular}

\begin{tabular}{ccccc}
\hline \multicolumn{4}{c}{ Richness of Species } \\
\hline & Estimates & $\operatorname{Pr}(>|\mathbf{t}|)$ & R-marginal & R-conditional \\
\hline Intercept & 13.69 & $<0.001 * *$ & & \\
Grasses Cover (\%) & -0.1 & $<0.001 * *$ & 0.65 & 0.99 \\
Aboveground biomass (Mg ha-1) & -0.1 & $<0.001 * *$ & &
\end{tabular}

\begin{tabular}{ccccc}
\hline \multicolumn{6}{c}{ Diversity of Simpson } \\
\hline & Estimates & $\operatorname{Pr}(>|\mathbf{t}|)$ & R-marginal & R-conditional \\
\hline Intercept & 0.27 & $<0.001^{* *}$ & & 0.005 \\
Grasses Cover (\%) & 0.001 & 0.797 & & 0.005 \\
\hline
\end{tabular}

Soil covariates did not impose limitations to natural tree regenerating vegetation, but some physical and chemical soil conditions positively influenced the forest tree recruitment. The effect of soil properties on survival and development of plants has been well-established in reforestation (van Breugel et al., 2011; Sobanski \& Marques, 2014). Clay particles are the main source of reactive processes in soil; are an important nutrient supply and water retention (Letey, 1985). However, our results suggest a negative correlation of clay content to plant height.

Water availability (WA) indicates the available soil water content for the plants without restriction of soil retention energy, i.e. the water that plant roots can remove from the soil porous system (Letey, 1985; Da Silva et al., 1994; Asgarzadeh et al., 2010). The reduced water availability implies in a lower number of individuals (Ferreira-Júnior et al., 2007), and lower vegetative biomass (Botrel et al., 2002; Dalanesi et al., 2004). Our result of a positive 
correlation of WA with the number of individuals also highlights the importance of that covariate, corroborating previous studies (Asgarzadeh et al., 2010).

Cation exchange capacity (CEC) had a positive correlation with the number of individuals. CEC is the amount of the cation exchange capacity, which integrates important cations for plants (Ca, K, Mg). An increase of CEC leads to an increase in the availability of nutrients for plants in the soil (although the availability of these nutrients for the plants is dependent on soil acidity, i.e. pH) (Saidi, 2012), which are essential elements for plant growth. A positive impact on the number of individuals was observed at SMFP.

The variation in soil fertility affects species distribution in a plant community (Parrotta et al., 1997; Clark et al., 1999; Oliveira-Filho et al., 2001; Frizano et al., 2003; FerreiraJúnior et al., 2007; van Breugel et al., 2011). During reforestation, this variation can change the forest structure patterns (van Breugel et al., 2011). Some studies suggest that the deficiency of potassium $\left(\mathrm{K}^{+}\right)$and phosphorus $(\mathrm{P})$ are limiting to the growth of mature forests (Tripler et al., 2006; Laclau et al., 2008; Wright et al., 2011) while abundant $\mathrm{K}^{+}$has a positive correlation to aboveground growth (Tripler et al., 2006). In our study, soil $\mathrm{K}^{+}$is implicit in CEC, and we observed a positive relationship with the number of individuals, corroborating previous research. We emphasize that we avoided using variables solely such as $\mathrm{K}$, to avoid multicollinearity issues.

The soil class did not affect the regeneration layer. It is well known that the physical, chemical, and biological characteristics of the soil vary according to soil classes. However, adding this level of information did not improve the model's performance. We believe that only two classes, as carried out in this study, were not sufficient to verify any effect on the regeneration layer, and multiple classes of soils should be considered in future studies to better clarify this potential relationship most effectively.

\subsection{The impact of the invasive African grasses interference on the forest regeneration}

The grass cover by invasive African species had a negative correlation on the number of individuals, species richness, and regenerate's height (Table 3). The African grasses were initially introduced in Brazil as forage material for cattle (Zenni \& Ziller, 2011); however, some species dispersed from the original location of introduction becoming invasive species (Moro et al., 2012). The presence of those species in native areas and reforestation projects is widely reported (Flory \& Clay, 2010; Meli \& Dirzo, 2013; Damasceno et al., 2018). The interference imposed by invasive African grasses on tree regeneration has been a problem (D'Antonio \& Vitousek, 1992; D'Antonio et al., 1998; Sharma \& Raghubanshi, 2010). In a Brazilian natural savanna, all native functional groups of the natural regeneration were reduced as a consequence of two invasive African grasses, Urochloa brizantha and Melinis minutiflora (Damasceno et al., 2018).

Damasceno et al. (2018) observed a negative impact of invasive African grasses on natural regeneration in the dry season, corroborating our results. Holl (1999) observed significantly higher seed germination in a pasture with grasses than pasture cleared of grasses during the dry season; however the differences were mostly evident in the rainy season. We observed that when we used the additional information of canopy openness and grass cover from the rainy season, the models had the poorest performance. 
Contrastingly, Meli \& Dirzo (2013) did not observe any interference by invasive grasses on native seedlings. However, Meli \& Dirzo (2013) examined saplings instead of regenerating trees. As such, we expect a well-developed root system with a higher water capacity and nutrients assimilation for saplings (Flory \& Clay, 2010; Meli \& Dirzo, 2013), differently from this study, where the plants were all germinated by seeds dispersed from local and nearby trees. During natural regeneration, plants have been exposed to barriers to germination, growth, and survival due to the presence of invasive African grasses. Consequently, the numbers of individuals and species richness were both negatively affected by a layer of biomass promoted by the invasive African grasses, which imposed barriers to the development of plant growth.

In the Neotropical Savanna, the exotic grasses have imposed a limitation on the seedling survival and growth of the native species and the seedlings survival was negatively correlated with the biomass of the grasses, as a consequence of the competition for light (Hoffmann \& Haridasan, 2008). Although the biomass on the ground may keep the humidity and reduce the temperature of soil top layers, which is important to the seed germination, it does not seem that it is an important factor to facilitate the growth and survival of native seedlings.

\subsection{The impact of the tree vegetation layer on the forest regeneration}

While soil properties and grass cover have been demonstrated to be important for forest recruitment, establishment and growth; light is also likely important for forest regeneration. The availability of light inside the lower canopy of the forest leads to an alteration on both structure and diversity dynamics of the forest regeneration layer and is a phenomenon often associated with the formation of gaps in mature and secondary forests. Forest gaps have been extensively reported in tropical forests where gap formation is usually due to tree falls (Denslow, 1987; de Lima \& de Moura, 2008; Sapkota \& Odén, 2009).

Particularly in SMFP, an earlier study by Colmanetti \& Barbosa (2013) nine years after planting observed that most of the species planted during reforestation were present in the tree layer, suggesting that gaps may be not solely associated with tree mortality, but also with the low age of reforestation. Most of the species composition in the tree layer were originally used during the reforestation of the park; therefore, Colmanetti \& Barbosa (2013) speculated that canopy openness could be more related to failures in the planting than to fallen trees. Although the replanting was done at SMFP, we speculate that tree mortality could have happened in the first years after planting and replanting.

Although the present study did not focus on structural characterization and dynamics of the tree layer, we emphasize that the tree layer plays a strong influence on the regeneration layer, and is essential to regulate the entrance of light into the lower canopy. Deciduous species in the tree layer were an important factor for tree regeneration layer establishment. These deciduous species drop their leaves in the dry season forming virtual gaps leading to changes in brightness throughout the year (Gandolfi et al., 2007). The effective interference of the canopy dynamism (opening and subsequent filling of canopy gaps) throughout the year on the regeneration layer (Guariguata \& Ostertag, 2001) could not be corroborated by our results. Canopy openness was not a strong explanatory variable for the regeneration layer in the rainy season, but had some explanatory importance from the dry season in the models. Efforts using multiple measurements throughout the year are necessary for a better 
understanding of the real role on the canopy openness variability on the regenerating layer, and its interaction with soil and grass cover.

\section{CONCLUSIONS}

Soil properties did not impose any restriction to the natural forest recruitment or growth, except by clay content. In contrast, the grass cover by invasive African species imposed a strong negative pressure on the number of individuals. Since it is expected that seedlings will grow and become the tree layer over the time, the negative interference imposed by the grass cover on species richness, diversity, and number of individuals may alter the composition of the tree layer in the future. The results we observed are still preliminary, since the reforestation was only 10 years old, and further studies based on older stages are required to verify how the vegetation changes over time.

\section{REFERENCES}

Alvares, C. A., Stape, J. L., Sentelhas, P. C., de Moraes Gonçalves, J. L., \& Sparovek, G. (2013). Köppen's climate classification map for Brazil. Meteorologische Zeitschrift (Berlin), 22(6), 711-728. http://dx.doi.org/10.1127/0941-2948/2013/0507.

Asgarzadeh, H., Mosaddeghi, M. R., Mahboubi, A. A., Nosrati, A., \& Dexter, A. R. (2010). Integral energy of conventional available water, least limiting water range and integral water capacity for better characterization of water availability and soil physical quality. Geoderma, 166(1), 34-42. http://dx.doi.org/10.1016/j.geoderma.2011.06.009.

Botrel, R. T., Oliveira Filho, A. T., Rodrigues, L. A., \& Curi, N. (2002). Influência do solo e topografia sobre as variações da composição florística e estrutura da comunidade arbóreo-arbustiva de uma floresta estacional semidecidual em Ingaí, MG. Revista Brasileira de Botanica. Brazilian Journal of Botany, 25(2), 195-213. http://dx.doi.org/10.1590/S0100-84042002000200008.

van Breugel, M., Hall, J. S., Cravena, D. J., Gregoire, T.G., Park, A., Dent, D. H., Wishnie, M. H., Mariscal, E., Deago, J., Ibarra, D., Cedeño, N., \& Ashton, M. S. (2011). Early growth and survival of 49 tropical tree species across sites differing in soil fertility and rainfall in Panama. Forest Ecology and Management, 261(10), 1580-1589. https://doi.org/10.1016/j.foreco.2010.08.019.

Camargo, O. A., Moniz, A.C., Jorge, J.A., \& Valadares, J.M.A.S. (1986). Métodos de análise química, mineralógica e física de solos do Instituto Agronômico de Campinas. Campinas: Instituto Agronômico.

Chazdon, R. L., Finegan, B., Capers, R. S., Salgado-Negret, B., Casanoves, F., Boukili, V., \& Norden, N. (2010). Composition and dynamics of functional groups of trees during tropical forest succession in northeastern Costa Rica. Biotropica, 42(1), 31-40. http://dx.doi.org/10.1111/j.17447429.2009.00566.x.

Clark, D. B., Palmer, M. W., \& Clark, D. A. (1999). Edaphic Factors and the Landscape-Scale Distributions of Tropical Rain Forest Trees. Ecology, 80(8), 2662-2675. http://dx.doi.org/10.2307/177248.

Colmanetti, M. A. A. (2013). Estrutura da vegetação e características edáficas de um reflorestamento com espécies nativas. (Dissertação de mestrado). Instituto de Botânica, São Paulo.

Colmanetti, M. A. A., Barbosa, L. M., Shirasuna, R. T., \& Couto, H. T. Z. (2016). Phytosociology and structural characterization of woody regeneration from a reforestation with native species in Southeastern Brazil. Revista Árvore, 40(2), 209-218. http://dx.doi.org/10.1590/010067622016000200003.

Colmanetti, M. A. A., \& Barbosa, L. M. (2013). Fitossociologia e estrutura do estrato arbóreo de um reflorestamento com espécies nativas em Mogi-Guaçu, SP, Brasil. Hoehnea, 40(3), 419-435. http://dx.doi.org/10.1590/S2236-89062013000300003.

D'Antonio, C. M., Hughes, R. F., Mack, M., Hitchcock, D., \& Vitousek, P. M. (1998). The response of native species to removal of invasive exotic grasses in a seasonally dry Hawaiian woodland. Journal of Vegetation Science, 9(5), 699-712. http://dx.doi.org/10.2307/3237288.

D'Antonio, C. M., \& Vitousek, P. M. (1992). Biological invasions by exotic grasses, the grass/fire cycle, and global change. Annual Review of Ecology and Systematics, 23(1), 63-87. http://dx.doi.org/10.1146/annurev.es.23.110192.000431. 
Silva, A. P., Ball, B. C., Tormena, C. A., Giarola, N. F. B., \& Guimarães, R. M. L. (2014). Soil structure and greenhouse gas production differences between row and interrow positions under no-tillage. Scientia Agrícola, 71(2), 157-162. http://dx.doi.org/10.1590/S0103-90162014000200011.

Da Silva, A. P., Kay, B. D., \& Perfect, E. (1994). Characterization of the least limiting water range of soils. Soil Science Society of America Journal, 58(6), 1775. http://dx.doi.org/10.2136/sssaj1994.03615995005800060028x.

Dalanesi, P. E., de Oliveira-Filho, A. T., \& Fontes, M. A. L. (2004). Flora e estrutura do componente arbóreo da floresta do Parque Ecológico Quedas do Rio Bonito, Lavras, MG, e correlações entre a distribuição das espécies e variáveis ambientais. Acta Botanica Brasílica, 18(4), 737-757. http://dx.doi.org/10.1590/S0102-33062004000400005.

Damasceno, G., Souza, L., Pivello, V., Gorgone-Barbosa, E., Giroldo, P.Z., \& Fidelis, A. (2018). Impact of invasive grasses on Cerrado under natural regeneration. Biological Invasions, 20, 3621-3629.

Denslow, J. S. (1987). Tropical rainforest gaps and tree species diversity. Annual Review of Ecology and Systematics, 18(1), 431-451.http://dx.doi.org/10.1146/annurev.es.18.110187.002243.

Denslow, J. S., \& Guzman, G. (2000). S. Variation in stand structure, light and seedling abundance across a tropical moist forest chronosequence, Panama. Journal of Vegetation Science, 11(2), 201-212. http://dx.doi.org/10.2307/3236800.

Ferreira-Júnior, W. G., Silva, A. F., Schaefer, C. E. G. R., Meira Neto, J. A. A., Dias, A. S., Ignácio, M., \& Medeiros, M. C. M. P (2007). Influence of soils and topographic gradients on tree species distribution in a Brazilian Atlantic tropical semideciduous forest. Edinburgh Journal of Botany, 64(2), 137-157. http://dx.doi.org/10.1017/S0960428607000832.

Filho, O. G.; Blanco-Canqui, H.; Da Silva, A. P. (2013). Least limiting water range of the soil seedbed for long-term tillage and cropping systems in the central Great Plains, USA. Geoderma, 207-208(1), 99110. http://dx.doi.org/10.1016/j.geoderma.2013.05.008.

Flory, S. L., \& Clay, K. (2010). Non-native grass invasion suppresses forest succession. Oecologia, 164(4), 1029-1038. PMid:20582439. http://dx.doi.org/10.1007/s00442-010-1697-y.

Frizano, J., Vann, D. R., Johnson, A. H., Johnson, C. M., Vieira, I. C. G., \& Zarin, D. J. (2003). Labile Phosphorus in Soils of Forest Fallows and Primary Forest in the Bragantina Region, Brazil. Biotropica, 35(1), 2-11. http://dx.doi.org/10.1111/j.1744-7429.2003.tb00256.x.

Gandolfi, S., Joly, C. A., \& Rodrigues, R. R. (2007). Permeability - impermeability: canopy trees as biodiversity filters. Scientia Agrícola, 64(4), 433-438. http://dx.doi.org/10.1590/S010390162007000400015

Guariguata, M. R., \& Ostertag, R. (2001). Neotropical secondary forest succession: changes in structural and functional characteristics. Forest Ecology and Management, 148(1-3), 185-206. http://dx.doi.org/10.1016/S0378-1127(00)00535-1.

Hoffmann, W. A., \& Haridasan, M. (2008). The invasive grass, Melinis minutiflora, inhibits tree regeneration in a Neotropical savanna. Austral Ecology, 33(1), 29-36. http://dx.doi.org/10.1111/j.1442-9993.2007.01787.x.

Holl, K. D. (1998). Effects of above- and below-ground competition of shrubs and grass on Calophyllum brasiliense (Camb.) seedling growth in abandoned tropical pasture. Forest Ecology and Management, 109(1-3), 187-195. http://dx.doi.org/10.1016/S0378-1127(98)00248-5.

Holl, K. D. (1999). Factors limiting tropical rain forest regeneration in abandoned pasture: Seed factors limiting tropical rain forest regeneration in abandoned pasture: Seed rain, seed germination, microclimate, and soil. Biotropica, 31(2), 229-242. http://dx.doi.org/10.1111/j.17447429.1999.tb00135.x.

Laclau, J. P., Almeida, J. C., Gonçalves, J. L., Saint-André, L., Ventura, M., Ranger, J., Moreira, R. M., \& Nouvellon, Y. (2008). Influence of nitrogen and potassium fertilization on leaf lifespan and allocation of above-ground growth in Eucalyptus plantations. Tree Physiology, 29(1), 111-124. PMid:19203937. http://dx.doi.org/10.1093/treephys/tpn010.

Leitão, F. H. M., Marques, M. C. M., \& Ceccon, E. (2010). Young restored forests increase seedling recruitment in abandoned pastures in the Southern Atlantic rainforest. Revista de Biología Tropical, 58(4), 1271-1282. PMid:21246991.

Letey, J. (1985). Relationship between soil physical properties and crop production. Advances in Soil Science, 1, 277-294.

de Lima, R. A. F., \& de Moura, L. C. (2008). Gap disturbance regime and composition in the Atlantic Montane Rain Forest: the influence of topography. Plant Ecology, 197(2), 239-253. http://dx.doi.org/10.1007/s11258-007-9374-x. 
Meli, P., \& Dirzo, R. (2013). Effects of grasses on sapling establishment and the role of transplanted saplings on the light environment of pastures: implications for tropical forest restoration. Applied Vegetation Science, 16(2), 296-304. http://dx.doi.org/10.1111/j.1654-109X.2012.01217.x.

Moro, M. F., Souza, V. C., Oliveira-Filho, A. T., Queiroz, L. P., Fraga, C. N., Rodal, M. J. N., Araújo, F. S., \& Martins, F. R. (2012). Alienígenas na sala: o que fazer com espécies exóticas em trabalhos de taxonomia, florística e fitossociologia? Acta Botanica Brasílica, 26(4), 991-999. http://dx.doi.org/10.1590/S0102-33062012000400029.

Oliveira-Filho, A. T., Curi, N., Vilela, E. A., \& Carvalho, D. A. (2001). Variation in tree community composition and structure with changes in soil properties within a fragment of semideciduous forest in Southeastern Brazil. Edinburgh Journal of Botany, 58(1), 139-158. http://dx.doi.org/10.1017/S0960428601000506.

Parrotta, J. A., Knowles, O. H., \& Wunderle Junior, J. M. (1997). Development of floristic diversity in 10 years old restoration forests on a bauxite mined site in Amazonia. Forest Ecology and Management, 99(1-2), 21-42. http://dx.doi.org/10.1016/S0378-1127(97)00192-8.

Pereira, L. C. S. M., Oliveira, C. C. C., \& Torezan, J. M. D. (2013). Woody species regeneration in atlantic forest restoration sites depends on surrounding landscape. Natureza \& Conservação, 11(2), 138-144. http://dx.doi.org/10.4322/natcon.2013.022.

R Core Team. (2018). R: A language and environment for statistical computing. Recuperado em 20 de julho de 2010, de https://www.r-project.org/

Rodrigues, R. R., Lima, R. A. F., Gandolfi, S., \& Nave, A. G. (2009). On the restoration of high diversity forests: 30 years of experience in the Brazilian Atlantic Forest. Biological Conservation, 142(6), 1242 1251. http://dx.doi.org/10.1016/j.biocon.2008.12.008

Rodrigues, R. R., Gandolfi, S., Nave, A. G., Aronson, J., Barreto, T. E., Vidal, C. Y., \& Brancalion, P. H. S. (2011). Large-scale ecological restoration of high-diversity tropical forests in SE Brazil. Forest Ecology and Management, 261(10), 1605-1613. http://dx.doi.org/10.1016/j.foreco.2010.07.005.

Saidi, D. (2012). Importance and role of cation exchange capacity on the physicals properties of the Cheliff saline soils (Algeria). Procedia Engineering, 33(2011), 435-449,.

Sapkota, I. P., \& Odén, P. C. (2009). Gap characteristics and their effects on regeneration, dominance and early growth of woody species. Journal of Plant Ecology, 2(1), 21-29. http://dx.doi.org/10.1093/jpe/rtp004.

Sharma, G. P., \& Raghubanshi, A. S. (2010). How Lantana invades dry deciduous forest: A case study from Vindhyan highlands, India. Tropical Ecology, 51(2, Suppl.), 305-316.

Shono, K., Davies, S. J., \& Kheng, C. Y. (2006). Regeneration of native plant species in restored forests on degraded lands in Singapore. Forest Ecology and Management, 237(1-3), 574-582. http://dx.doi.org/10.1016/j.foreco.2006.10.003.

Simpson, E.H. (1949). Measurement of Diversity. Nature, 163(1946), 688. https://doi.org/10.1038/163688a0

Sobanski, N., \& Marques, M. C. M. (2014). Effects of soil characteristics and exotic grass cover on the forest restoration of the Atlantic Forest region. Journal for Nature Conservation, 22(3), 217-222. http://dx.doi.org/10.1016/j.jnc.2014.01.001.

Soil Survey Staff, 2014. Keys to Soil Taxonomy. 12th ed. Washington, DC: US Department of AgricultureNatural Resources Conservation Service.

Sotomayor, J. F. M. (2013). Determinação de biomassa aérea em florestas nativas num ambiente agrícola do Estado de São Paulo. University of São Paulo.

Stevens, P. F. (2001). Angiosperm Phylogeny Website. Recuperado em 20 de julho de 2011, de http://www.mobot.org/MOBOT/research/APweb/

Tripler, C. E., Kaushal, S. S., Likens, G. E., \& Walter, M. T. (2006). Patterns in potassium dynamics in forest ecosystems. Ecology Letters, 9(4), 451-466. PMid:16623731. http://dx.doi.org/10.1111/j.14610248.2006.00891.x.

Teixeira, P. C., Donagemma, G. K., Fontana., A., Teixeira, W. G. (2017). Manual de Métodos de Análise de Solo (573 p.). Brasília: Embrapa.

Wright, S. J., Yavitt, J. B., Wurzburger, N., Turner, B. L., Tanner, E. V., Sayer, E. J., Santiago, L. S., Kaspari, M., Hedin, L. O., Harms, K. E., Garcia, M. N., \& Corre, M. D. (2011). Potassium, phosphorus, or nitrogen limit root allocation, tree growth, or litter production in a lowland tropical forest. Ecology, 92(8), 1616-1625. PMid:21905428. http://dx.doi.org/10.1890/10-1558.1. 
Zenni, R. D., \& Ziller, S. R. (2011). An overview of invasive plants in Brazil. Revista Brasileira de Botanica. Brazilian Journal of Botany, 34(3), 431-446. http://dx.doi.org/10.1590/S0100-84042011000300016.

Authors' contributions: MAAC: Conceptualization, Formal Analysis, Writing - original draft, Writing - review \& editing; LMB: Conceptualization, Project administration, Supervision; HTZC: Formal Analysis, Methodology; JCC: Methodology, Writing - review \& editing; RTS: Validation; PRTO: Validation; RPL: Methodology, Writing - review \& editing; MMD: Funding acquisition, Project administration, Resources. 


\section{APPENDIX 1}

Pearson correlation for variables and covariates. P - phosphorus, O.M. - organic matter, CEC - cation exchange capacity, FC-PWP - water availability, V - base saturation. Bold numbers are statistically significant at $95 \%$ level of confidence.

\begin{tabular}{|c|c|c|c|c|c|c|c|c|c|c|c|c|c|c|}
\hline & 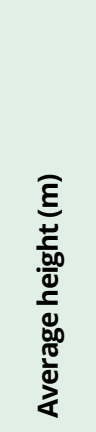 & 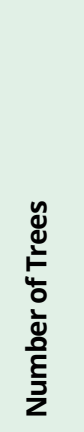 & 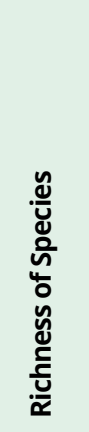 & 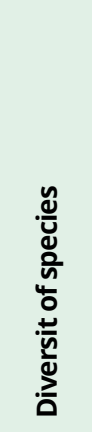 & 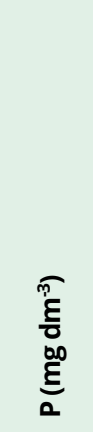 & 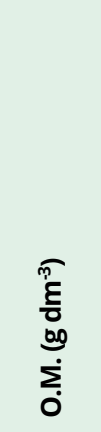 & 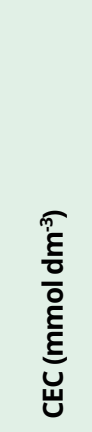 & 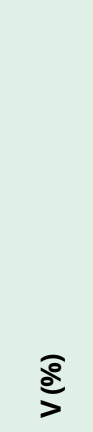 & 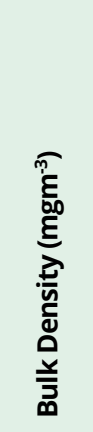 & 芳 & 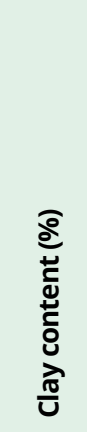 & 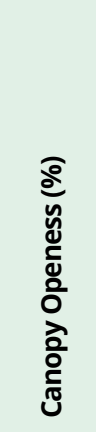 & 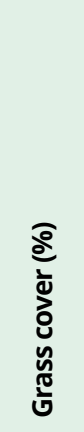 & 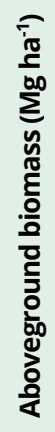 \\
\hline Height & 1 & & & & & & & & & & & & & \\
\hline N.Trees & -0.16 & 1 & & & & & & & & & & & & \\
\hline Richness of Species & 0.13 & 0.57 & 1 & & & & & & & & & & & \\
\hline Diversity & -0.001 & 0.01 & -0.43 & 1 & & & & & & & & & & \\
\hline $\mathrm{P}\left(\mathrm{mg} \mathrm{dm}^{-3}\right)$ & 0.04 & -0.08 & 0.23 & -0.15 & 1 & & & & & & & & & \\
\hline O.M. $\left(\mathrm{g} \mathrm{dm}^{-3}\right)$ & 0.05 & -0.16 & -0.07 & -0.18 & 0.21 & 1 & & & & & & & & \\
\hline $\mathrm{CEC}\left(\mathrm{mmol} \mathrm{dm} \mathrm{m}^{-3}\right)$ & -0.07 & 0.54 & 0.19 & -0.17 & -0.03 & 0.32 & 1 & & & & & & & \\
\hline V (\%) & -0.27 & -0.17 & -0.22 & 0.04 & 0.34 & 0.1 & -0.10 & 1 & & & & & & \\
\hline Bulk Density $\left(\mathrm{mgm}^{-3}\right)$ & -0.04 & 0.28 & 0.26 & 0.15 & 0.1 & -0.35 & -0.14 & 0.20 & 1 & & & & & \\
\hline FC-PWP & -0.07 & 0.54 & 0.31 & -0.10 & -0.25 & -0.02 & 0.45 & -0.38 & 0.1 & 1 & & & & \\
\hline Clay content (\%) & -0.20 & 0.10 & -0.12 & -0.04 & -0.38 & 0.1 & 0.36 & -0.43 & -0.58 & 0.48 & 1 & & & \\
\hline Canopy Openess (\%) & -0.45 & -0.10 & -0.11 & 0.26 & -0.23 & 0.01 & 0.15 & -0.08 & -0.19 & 0.08 & 0.23 & 1 & & \\
\hline Grass cover (\%) & -0.11 & -0.53 & -0.74 & 0.24 & -0.28 & -0.002 & -0.38 & 0.26 & -0.1 & -0.51 & -0.14 & 0.20 & 1 & \\
\hline $\begin{array}{c}\text { Aboveground } \\
\text { biomass (Mg ha-1) }\end{array}$ & 0.24 & -0.34 & 0.21 & 0.07 & -0.07 & 0.15 & -0.24 & -0.17 & -0.07 & -0.10 & 0.04 & -0.12 & 0.03 & 1 \\
\hline
\end{tabular}




\section{APPENDIX 2}

Species and families from the tree layer in "São Marcelo" Forest Park at Mogi Guaçu, Brazil. **Exotic species in Atlantic forest.

\section{Anacardiaceae}

Astronium fraxinifolium Schott

Astronium graveolens Jacq.

Lithrea molleoides (Vell.) Engl.

Myracrodruon urundeuva Allemão

Schinus molle L.

Schinus terebinthifolius Raddi

Tapirira guianensis Aubl.

\section{Apocynaceae}

Aspidosperma cylindrocarpon Müll. Arg.

Aspidosperma polyneuron Müll. Arg.

Tabernaemontana hystrix Steud.

\section{Asteraceae}

Gochnatia polymorpha (Less.) Cabrera

Bignoniaceae

Handroanthus heptaphyllus (Vell.) Mattos

Handroanthus impetiginosus Mattos

Handroanthus ochraceus (Cham.) Mattos

Handroanthus serratifolius (A.H.Gentry) S.Grose

Handroanthus sp.

Jacaranda cuspidifolia Mart.

Jacaranda mimosifolia D. Don**

Tabebuia roseoalba (Ridl.) Sandwith

Tecoma stans (L.) Juss. ex Kunth**

Zeyheria tuberculosa (Vell.) Bureau ex Verl.

\section{Boraginaceae}

Cordia abyssinica R. Br. ex A. Rich.**

Cordia trichotoma (Vell.) Arráb. ex Steud.

\section{Euphorbiaceae}

Alchornea glandulosa Poepp. \& Endl.

Croton floribundus Spreng.

Croton urucurana Baill.

Mabea fistulifera Mart.

\section{Fabaceae}

Albizia niopoides (Spruce ex Benth.) Burkart

Anadenanthera colubrina (Vell.) Brenan

Anadenanthera colubrina var. cebil (Griseb.) Altschul 
Bauhinia sp.

Cassia leptophylla Vogel

Copaifera langsdorffii Desf.

Enterolobium contortisiliquum (Vell.) Morong

Hymenaea courbaril L. var. stilbocarpa (Hayne) Y.T. Lee \& Langenh.

Inga vera subsp. affinis (DC.) T. D. Penn.

Machaerium aculeatum Raddi

Mimosa bimucronata (DC.) Kuntze

Myroxylon peruiferum L.f.

Parapiptadenia rigida (Benth.) Brenan

Peltophorum dubium (Spreng.) Taub.

Poecilanthe parviflora Benth.

Pterocarpus rohrii Vahl

Pterogyne nitens Tul.

Schizolobium parahyba (Vell.) Blake

Senegalia polyphylla (DC.) Britton \& Rose

Senna multijuga (Rich.) H.S. Irwin \& Barneby

\section{Lamiaceae}

Aegiphila integrifolia (Jacq.) Moldenke

\section{Lauraceae}

Nectandra megapotamica (Spreng.) Mez

\section{Lythraceae}

Lafoensia glyptocarpa Koehne

Lafoensia pacari A.St.-Hil.

\section{Malvaceae}

Bastardiopsis densiflora (Hook. \& Arn.) Hassl.

Ceiba speciosa (A. St.-Hil.) Ravenna

Guazuma ulmifolia Lam.

Luehea divaricata Mart. \& Zucc.

\section{Meliaceae}

Cedrela fissilis Vell.

Cedrela odorata L.

Melia azedarach L.**

Moraceae

Ficus enormis Mart. ex Miq.

Maclura tinctoria (L.) D.Don ex Steud.

\section{Myrsinaceae}

Myrsine umbellata Mart.

\section{Myrtaceae}

Eugenia uniflora L. 
Psidium guajava L.**

Eucalyptus sp. **

\section{Phytolaccaceae}

Gallesia integrifolia (Spreng.) Harms

\section{Polygonaceae}

Triplaris americana L.

\section{Rhamnaceae}

Colubrina glandulosa Perkins

Rhamnidium elaeocarpum Reissek

\section{Rosaceae}

Prunus myrtifolia (L.) Urb.

\section{Rubiaceae}

Genipa americana L.

\section{Rutaceae}

Balfourodendron riedelianum (Engl.) Engl.

Dictyoloma vandellianum A.Juss.

Salicaceae

Casearia cf. decandra Jacq.

Urticaceae

Cecropia pachystachya Trécul

\section{Verbenaceae}

Aloysia virgata (Ruiz \& Pav.) Juss.

Citharexylum myrianthum Cham. 


\section{APPENDIX 3}

Species and families from the natural forest recruitment layer in "São Marcelo" Forest Park at Mogi Guaçu, Brazil. **Exotic species in Atlantic forest.

\section{Anacardiaceae}

Myracrodruon urundeuva Allemão

Schinus terebinthifolius Raddi

\section{Annonaceae}

Xylopia aromatica (Lam.) Mart.

\section{Apocynaceae}

Aspidosperma cylindrocarpon Müll.Arg.

Aspidosperma polyneuron Müll.Arg.

Tabernaemontana hystrix Steud.

\section{Araliaceae}

Dendropanax cuneatus (DC.) Decne. \& Planch.

\section{Arecaceae}

Syagrus romanzoffiana (Cham.) Glassman

\section{Asteraceae}

Gochnatia polymorpha (Less.) Cabrera

\section{Bignoniaceae}

Handroanthus heptaphyllus (Vell.) Mattos

Handroanthus cf. serratifolius (A.H.Gentry) S.Grose

Handroanthus ochraceus (Cham.) Mattos

Handroanthus sp.

Tabebuia roseoalba (Ridl.) Sandwith

Zeyheria tuberculosa (Vell.) Bureau ex Verl.

\section{Boraginaceae}

Cordia sp.

\section{Cannabaceae}

Trema micantha (L.) Blume

\section{Erythroxylaceae}

Erythroxylum campestre A.St.-Hil.

\section{Euphorbiaceae}

Alchornea glandulosa Poepp. \& Endl.

Croton floribundus Spreng.

Croton urucurana Baill.

Mabea fistulifera Mart.

Pera glabrata (Schott) Poepp. ex Baill.

\section{Fabaceae}

Anadenanthera sp.

Bauhinia forficata Link 
Copaifera langsdorffii Desf.

Inga vera subsp. affinis (DC.) T.D.Penn.

Mimosa bimucronata (DC.) Kuntze

Mimosa caesalpiniifolia Benth.**

Machaerium sp.

Parapiptadenia rigida (Benth.) Brenan

Pterocarpus rohrii Vahl

Schizolobium parahyba (Vell.) Blake

Senna multijuga (Rich.) H.S.Irwin \& Barneby

Senegalia polyphylla (DC.) Britton \& Rose

Tecoma stans (L.) Juss. ex Kunth**

\section{Lamiaceae}

Vitex sp.

\section{Lauraceae}

Nectandra megapotamica (Spreng.) Mez

\section{Lythraceae}

Lafoensia pacari A.St.-Hil.

\section{Malvaceae}

Bastardiopsis densiflora (Hook. \& Arn.) Hassl.

Heliocarpus popayanensis Kunth

Luehea divaricata Mart. \& Zucc.

\section{Meliaceae}

Melia azedarach L.**

Moraceae

Maclura tinctoria (L.) D.Don ex Steud.

Ficus sp.

Myrsinaceae

Myrsine coriacea (Sw.) R.Br. ex Roem.\& Schult.

Myrsine umbellata Mart.

\section{Myrtaceae}

Eugenia uniflora $\mathrm{L}$.

Psidium guajava L.**

\section{Phytolaccaceae}

Gallesia integrifolia (Spreng.) Harms

\section{Polygonaceae}

Triplaris americana L.

\section{Rhamnaceae}

Rhamnidium elaeocarpum Reissek

Colubrina glandulosa Pekins

Rosaceae 
Eriobotrya japonica (Thunb.) Lindl.**

Prunus myrtifolia (L.) Urb.

\section{Rubiaceae}

Coffea arabica L.**

\section{Rutaceae}

Dictyoloma vandellianum A. Juss.

Zanthoxylum riedelianum Engl.

\section{Sapindaceae}

Allophylus L.

\section{Urticaceae}

Cecropia pachystachya Trécul

\section{Verbenaceae}

Aloysia virgata (Ruiz \& Pav.) Juss.

Citharexylum myrianthum Cham. 